\title{
PERSISTENCE OF CADUSAFOS IN SOIL OF BANANA ORCHARD UNDER DIFFERENT ENVIRONMENTAL CONDITIONS
}

(Received:30.10. 2007)

\author{
By \\ N. S. Ahmed \\ Central Agricultural Pesticides Laboratory-Agricultural Research Center-Dokki- Giza- \\ Egypt
}

\begin{abstract}
The present study was conducted to follow up the residues of one example of an organophosphate nematicide recommended for controlling nematodes and soil insects namely cadusafos (rugby 10\%G). The experiment was done in banana orchard to study the persistence of cadusafos in sandy loam soil and banana fruits. The effect of hydrogen ion concentration, thermal and photolytic conditions on the persistence of cadusafos was studied. It was found that the initial deposit of cadusafos in the soil was $66.49 \mathrm{ppm}$ and the half-life period was 10.83 days. The results confirmed that the banana fruits can be used safely at any time after the application of the recommended dose of rugby $10 \% \mathrm{G}$. The higher stability of cadusafos was found under the two chosen temperatures $\left(30\right.$ and $\left.40^{\circ} \mathrm{C}\right)$. The half-life periods of cadusafos were 8.45 and 5.33 days under the conditions of UV-rays and sunlight, respectively. The alkaline medium showed a great effect on the persistence of cadusafos especially at higher temperature. In contrary, the neutral medium $(\mathrm{pH} \mathrm{7)}$ was less effective on the persistence of cadusafos.
\end{abstract}

Key words: nematicide, cadusafos, persistence, soil, banana fruits, thermal and photolytic degradation, hydrogen ion concentration

\section{INTRODUCTION}

Banana is the most important fruit crop commercially grown in a number of countries worldwide for its utilization as dessert and as staple food in certain parts of the world. Among the fruit crops, it is one of the most important crops in international trade for earning the foreign exchange in many African countries (Raut and Suvarna 2004). This fruit crop is mainly damaged and caused crop losses by nematodes which are nonsegmented, bilaterally symmetric worm-like invertibrates. Nematodes feed on microorganisms in water and soil (Ccobe 1914). Cadusafos is nonsystemic organophosphate insecticide used to control nematodes and soil insects on banana and other crops (McClure and Schmitt 1996). It is commercially applied to soils and subjected to biological and physicochemical transformations, depending on the physicochemical properties of the soil (Smelt and Leistra 1992) and (Nordmeyer and Maas 1992).
The present study aims to investigate

a) The rate of degradation in soil under banana trees and the residue of cadusafos The effect of in banana fruits.

b) The rate of degradation under two different temperatures $\left(30\right.$ and $40^{\circ} \mathrm{C}$ ), UVrays at $254 \mathrm{~nm}$, direct sunlight and hydrogen ion concentration $(\mathrm{pH})$ are also determined.

\section{MATERIALS AND METHODS}

\subsection{Field experiment}

\subsubsection{Sampling}

Cadusafos (rugby 10\%G):S,S-Di-secbutyl-O-ethylphosphorodithioate is soluble with water, miscible with most organic solvents, used to control various nematodes and insects in bananas, citrus and vegetables. Rugby $10 \% \mathrm{G}$ was applied at the rate of $20 \mathrm{gm} /$ hole by sowing the granules to a depth of about $10 \mathrm{~cm}$ from the top of the soil during February 2007 in Sadat city. Irrigation was done just after sowing. Soil samples $(500 \mathrm{gm})$ and banana fruits (250 gm) were taken at two hours intervals of 
after application (zero time), 7, 14, 21, 28, $35,42,49,63,77$ and 91 days from the beginning of the experiment. Three replicates of the subsamples of 50 and 100 gm from the fruits and the soil, respectively were preserved in clean polyethylene bags at $-20^{\circ} \mathrm{C}$ until use. The soil used in the experiment was sandy loam soil. The mechanical and physical characteristics of

Table (1): Mechanical and physical characteristics of tested soil

\begin{tabular}{|c|c|c|c|c|c|c|}
\hline \multicolumn{5}{|c|}{ Contents \% of sandy loam soil } & \multirow{2}{*}{$\begin{array}{c}\text { Organic } \\
\text { matter }\end{array}$} \\
$\begin{array}{c}\text { Coarse } \\
\text { sand }\end{array}$ & $\begin{array}{c}\text { Fine } \\
\text { sand }\end{array}$ & Silt & Clay & $\mathbf{C a C O}_{3}$ & pH & \\
\hline 2.73 & 61.22 & 21.13 & 14.92 & 1.52 & 7.5 & 1.4 \\
\hline
\end{tabular}

the used soil are presented in Table (1).

\subsubsection{Extraction}

A sample of $100 \mathrm{gm}$ of soil was shaked for one hour with $200 \mathrm{ml}$ of acetone - water $(3: 1 \mathrm{v} / \mathrm{v})$ according to the method of Krause et al., (1986). The extract was measured after decantation in a cylinder through a clean pad of cotton and concentrated to remove acetone and then re-extracted with $100 \mathrm{ml}$ methylene chloride for three times. The methylene chloride layer was dried through a dry pad of cotton and anhydrous sodium sulphate, then evaporated under vacuum to dryness for the step of cleaning up. Cadusafos was extracted from banana fruits using the method of Molhoff (1975) by adopting the method of using methanol instead of acetone. Frozen samples were left until reaching room temperatures. A sample $50 \mathrm{gm}$ of the fruit were mixed with $150 \mathrm{ml}$ methanol for $3 \mathrm{~min}$ in a warring blender at a high speed. The extract was filtered through a pad of cotton into a graduated cylinder. The methanol extract was partitioned three times with 100, 50 and $50 \mathrm{ml}$ methylene chloride in a $500 \mathrm{ml}$ separatory funnel after adding $40 \mathrm{ml}$ of saturated sodium chloride solution. The combined methylene chloride phases were filtered through a pad of cotton and anhydrous sodium sulphate then evaporated under vacuum till dryness at $40^{\circ} \mathrm{C}$ for the clean up procedure.

\subsubsection{Clean up}

Extracts of cadusafos were purified according to the method of Jhonson (1963) using the coagulating solution. The residues, dissolved in $5 \mathrm{ml}$ methanol, were mixed with $10 \mathrm{ml}$ of the fresh cold coagulating solution, transferred quantitatively and filtered through a column $2.5 \mathrm{~cm}$ diameter, $5 \mathrm{~cm}$ in length packed with $2.5 \mathrm{~cm}$ layer of celite 545. The dissolution was repeated four times. The collected solution was then subjected to separatory funnel with three times $25 \mathrm{ml}$ methylene chloride then over anhydrous sodium sulphate for the complete drying.

\subsubsection{Determination}

A Hewlett Packard, USA serial 6890 gas chromatograph equipped with a flame photometric detector operated in the phosphorus mode (526 nm filter) was used for cadusafos determination under the following conditions. The column was PAS1701 , ( $25 \mathrm{~m}$ length $\mathrm{x} 0.32 \mathrm{~mm}$ i.d.x $0.52 \mu \mathrm{m}$ film thickness). Temperatures were 245,185 and $250^{\circ} \mathrm{C}$ for injector, column and detector, respectively. Gases flow rates were 3,75 and $100 \mathrm{ml} / \mathrm{min}$ for nitrogen, hydrogen and air, respectively. At these conditions, the retention time of cadusafos was $2.2 \mathrm{~min}$. The rates of recovery for cadusafos were 98.93 and $97.82 \%$ for the fruits and soil, respectively.

\subsection{Thermal decomposition and photode- gradation of cadusafos}

One $\mathrm{ml}$ of ethyl acetate containing $100 \mu \mathrm{g}$ of cadusafos (a.i.) was spread as uniformly as possible on the surface of uncovered Petri dishes (5cm i.d.). Ethyl acetate was left to dry at room temperature and the resulting deposits were divided and subjected to different treatments.

The $1^{\text {st }}$ set of treatment Petri dishes was exposed to different temperatures $\left(30 \& 40^{\circ} \mathrm{C}\right)$ for $12,24,48,96,144$ and 240 hours inside a dark electric oven provided with a temperature regulating system to study the effect of different temperatures on the degradation of cadusafos.

The $2^{\text {nd }}$ set was exposed to short waves of an ultraviolet lamp at $254 \mathrm{~nm}$ at a distance of $12 \mathrm{~cm}$ for $1,3,6,9,12,15$ and 24 hours to study the effect of UV-rays on the degradation of cadusafos.

The $3^{\text {rd }}$ set was exposed to direct sunlight for $1,3,6,9,12,15$ and 24 hours to study the effect of direct sunlight on the degradation of cadusafos.

Dominating temperatures ranged between $38-41^{0} \mathrm{C}$

\subsection{Hydrolysis of cadusafos in different pH 7 and 9}


Aqueous buffers pH 7 and 9 were prepared. Certain amount of cadusafos was added to the buffer which fortified to reach $(5 \mu \mathrm{g} / \mathrm{ml})$. One liter of each $\mathrm{pH}$ was prepared in glass stoppered bottle and held in temperature-controlled incubators at 30 and $40^{\circ} \mathrm{C}$. After exposure to $6,12,24,48$, 96, 144 and 240 hours, duplicate samples from each temperature-pH combination were analyzed. Each sample $(20 \mathrm{ml})$ was extracted three times with methylene chloride $(10 \mathrm{ml})$ in a separatory funnel according to the method of Lee et al., (1989). The combined methylene chloride was dried over anhydrous sodium sulphate and evaporated till dryness. The residues were subjected to GC determination. The half-life time was calculated according to Moye et al., (1987).

\section{RESULTS AND DISCUSSION}

\subsection{Persistence of cadusafos in soil and} banana fruits under field condition

Data in Table (2) represent the residues of cadusafos in soil under banana fruits at different intervals. Data showed that the initial deposit of cadusafos in the soil was $66.50 \mathrm{ppm}$ after two hours of application. It decreased slowly during the experimental period and reached $7.90 \mathrm{ppm}$ after 91 days of application. Banana fruits showed no detectable residues during all days of the whole experiment. The estimated half life value of cadusafos in the soil was 10.83 day. The degradation in the soil was attributed to many factors such as the microbial degradation, alkalinity of the soil, or meteorological conditions (Jones and Norris., 1998 and Queneherve et al., 1991).

3.2. Effect of temperature, UV-rays and sunlight on the stability of cadusafos

\subsection{1-Effect of temperatures}

Data in Table (3) show the thermal decomposition of cadusafos at 30 and $40^{\circ} \mathrm{C}$ at different intervals up to 240 hours. The percent loss of cadusafos residues was 0.00 , $0.22,0.55,6.18,13.98$ and $26.06 \%$ at $30^{\circ} \mathrm{C}$ after $1 / 2,1,2,4,6$ and 10 days. The corresponding values at $40^{\circ} \mathrm{C}$ were 0.43 , $0.99,1.97,6.95,17.31$ and $31.52 \%$, respectively. It is clear as could be noticed from the table that cadusafos amount suffered progressive loss as temperature increased. The calculated half life periods of
Table (2): Residues of cadusafos in soil at different intervals after application.

\begin{tabular}{|c|c|c|}
\hline $\begin{array}{c}\text { Time } \\
\text { after } \\
\text { exposure } \\
\text { (days) }\end{array}$ & $\begin{array}{c}\text { Amount } \\
\text { recovered } \\
\text { (ppm) }\end{array}$ & \% loss \\
\hline 0 & 66.50 & 0.00 \\
7 & 42.97 & 35.38 \\
14 & 25.62 & 61.47 \\
21 & 20.82 & 68.69 \\
28 & 17.10 & 74.29 \\
35 & 15.93 & 76.05 \\
42 & 14.30 & 78.50 \\
49 & 13.48 & 79.73 \\
63 & 12.58 & 81.08 \\
77 & 9.80 & 85.26 \\
91 & 7.90 & 88.12 \\
\hline RL $_{50}$ in & \multicolumn{2}{|c|}{10.83} \\
days & \multicolumn{2}{|c}{} \\
\hline
\end{tabular}

this nematicide were 35.22 and 24.47 days at 30 and $40^{\circ} \mathrm{C}$, respectively. The stability of any pesticide is affected by many factors such as type of the pesticide, temperature applied and time of exposure. From the above results it is recommended to use cadusafos at the area of high temperature. Such results are in agreement with those obtained with Eissa et al., (2006).

\subsubsection{Effect of UV-rays and sunlight}

Table (3): Persistence of cadusafos under two different temperatures

\begin{tabular}{|c|c|c|c|c|}
\hline \multirow{3}{*}{$\begin{array}{c}\text { Time } \\
\text { of } \\
\text { expos } \\
\text { ure } \\
\text { (days) }\end{array}$} & \multirow{2}{*}{\multicolumn{2}{|c|}{$30^{0} \mathrm{C}$}} & \multirow{2}{*}{\multicolumn{2}{|c|}{$40^{\circ} \mathrm{C}$}} \\
\hline & & & & \\
\hline & $\begin{array}{c}\text { Amount } \\
\text { of } \\
\text { cadusafos } \\
(\mu \mathrm{g})\end{array}$ & $\%$ loss & $\begin{array}{c}\text { Amount } \\
\text { of } \\
\text { cadusafos } \\
(\mu \mathrm{g})\end{array}$ & $\%$ loss \\
\hline 0 & 100.00 & 0.00 & 100.00 & 0.00 \\
\hline $1 / 2$ & 100.00 & 0.00 & 99.57 & 0.43 \\
\hline 1 & 99.78 & 0.22 & 99.01 & 0.99 \\
\hline 2 & 99.45 & 0.55 & 98.03 & 1.97 \\
\hline 4 & 96.82 & 3.18 & 93.05 & 6.95 \\
\hline 6 & 88.02 & 11.98 & 82.69 & 17.31 \\
\hline 10 & 76.94 & 23.06 & 68.48 & 31.52 \\
\hline $\begin{array}{c}\mathrm{t}_{1 / 2} \\
\text { (days) }\end{array}$ & \multicolumn{2}{|c|}{35.22} & \multicolumn{2}{|c|}{24.47} \\
\hline
\end{tabular}

Data in Table (4) show that the decomposition percentage of cadusafos decreased gradually when exposed to UVrays. The percentage losses of the nematicide were $8.16,29.07,38.92,57.25$, $71.88,78.12$ and $87.68 \%$ after $1,3,6,9,12$, 15 and 24 hours, respectively. The residue half life value was 8.45 hours after exposure to UV-rays.

Data in Table (4) show also the persistence of cadusafos after exposure to direct sunlight, which was positively 
correlated with the exposure period. The results showed that the residues of cadusafos were $86.96 \mathrm{ppm}$ after one hour of exposure decreased to $5.54 \mathrm{ppm}$ after 24 hours from the direct sunlight exposure. The calculated half life values 5.33 hours, agreed with the result that obtained by Eissa et al., (2006). The radiation energy absorbed by the UV-rays of the sunlight $(>360 \mathrm{~nm})$ increases the transitional, vibrational, rotational and the electronic energy in which an electronically excited molecule might be resulted to obtain chemical modifications in the chemical structure in the pesticides. It was found that the exposure to sunlight was more effective than UV-rays $(254 \mathrm{~nm})$ in accelerating the photodecomposition of cadusafos. This might be due to thermal, evaporational and light intensity consideration Plimmer (1970)

\subsection{Effect of different $\mathrm{pH}$ solutions at the} temperatures 30 and $40^{\circ} \mathrm{C}$ on hydrolysis of cadusafos

Data in Table (5) show that the neutral conditions $(\mathrm{pH}=7)$ have a detectable effect for the degradation of cadusafos at 30 and $40^{\circ} \mathrm{C}$ with respect to that occurred by the
Table (4): Effect of UV-rays and direct sunlight on the

\begin{tabular}{|c|c|c|c|c|}
\hline \multirow{2}{*}{$\begin{array}{c}\text { Time of } \\
\text { exposure } \\
\text { (hours) }\end{array}$} & \multicolumn{2}{|c|}{ UV-rays } & \multicolumn{2}{|c|}{ Sunlight } \\
\hline & $\begin{array}{l}\text { Amount of } \\
\text { cadusafos } \\
(\mu \mathrm{g})\end{array}$ & $\%$ loss & $\begin{array}{c}\text { Amount } \\
\text { of } \\
\text { cadusafos } \\
(\mu \mathrm{g})\end{array}$ & $\%$ loss \\
\hline 0 & 100.00 & 0.00 & 100.00 & 0.00 \\
\hline 1 & 91.84 & 8.16 & 86.96 & 13.04 \\
\hline 3 & 70.93 & 29.07 & 61.42 & 38.58 \\
\hline 6 & 61.08 & 38.92 & 43.87 & 56.13 \\
\hline 9 & 42.75 & 57.25 & 31.74 & 68.26 \\
\hline 12 & 28.12 & 71.88 & 22.59 & 77.41 \\
\hline 15 & 21.88 & 78.12 & 16.21 & 83.79 \\
\hline 24 & 12.32 & 87.68 & 5.54 & 94.46 \\
\hline $\mathrm{t}_{1 / 2}$ (hours) & \multicolumn{2}{|c|}{8.45} & \multicolumn{2}{|c|}{5.33} \\
\hline
\end{tabular}

organophosphorus and carbamate pesticides in different media even acidic, neutral and alkaline one. The results showed a great decomposition for organophosphorus in the alkaline media rather than carbamate pesticides at the same media and vice versa.

From the above results, it is obvious to recommend cadusafos in the form of rugby $10 \% \mathrm{G}$ to injur nematodes in banana plantation safely without any detectable residues in the fruits which agreed with that obtained by Castillo et al.,(2006). It was

Table (5): Effect of different $\mathrm{pH}$ values at the temperature 30 or $40^{\circ} \mathrm{C}$ on the stability of cadusafos.

\begin{tabular}{|c|c|c|c|c|c|c|c|c|}
\hline \multirow{3}{*}{$\begin{array}{l}\text { Time of exposure } \\
\text { (days) }\end{array}$} & \multicolumn{4}{|c|}{$\mathrm{pH}=7$} & \multicolumn{4}{|c|}{$\mathbf{p H}=9$} \\
\hline & \multicolumn{2}{|l|}{$30^{0} \mathrm{C}$} & \multicolumn{2}{|l|}{$40^{\circ} \mathrm{C}$} & \multicolumn{2}{|c|}{$30^{0} \mathrm{C}$} & \multicolumn{2}{|c|}{$40^{\circ} \mathrm{C}$} \\
\hline & $\begin{array}{c}\text { Amount of } \\
\text { cadusafos }(\mu \mathrm{g})\end{array}$ & $\%$ loss & $\begin{array}{c}\text { Amount of } \\
\text { cadusafos }(\mu \mathrm{g})\end{array}$ & \% loss & $\begin{array}{c}\text { Amount of } \\
\text { cadusafos } \\
\mu \mathrm{g}\end{array}$ & \% loss & $\begin{array}{c}\text { Amount of } \\
\text { cadusafos } \\
\mu \mathrm{g}\end{array}$ & $\%$ loss \\
\hline $\begin{array}{c}0 \\
1 / 4 \\
1 / 2 \\
1 \\
2 \\
4 \\
6 \\
10 \\
\end{array}$ & $\begin{array}{c}100.00 \\
100.00 \\
99.88 \\
99.54 \\
98.07 \\
94.52 \\
84.73 \\
70.39 \\
\end{array}$ & $\begin{array}{c}0.00 \\
0.00 \\
0.12 \\
0.46 \\
1.93 \\
5.48 \\
15.27 \\
29.61 \\
\end{array}$ & $\begin{array}{c}100.00 \\
100.00 \\
98.60 \\
97.34 \\
96.02 \\
89.33 \\
86.94 \\
64.69 \\
\end{array}$ & $\begin{array}{c}0.00 \\
0.00 \\
1.40 \\
2.66 \\
3.98 \\
10.67 \\
13.06 \\
35.31 \\
\end{array}$ & $\begin{array}{c}100.00 \\
98.34 \\
94.27 \\
91.85 \\
84.77 \\
78.58 \\
69.20 \\
41.49 \\
\end{array}$ & $\begin{array}{c}0.00 \\
1.66 \\
5.73 \\
8.15 \\
15.23 \\
21.42 \\
30.80 \\
58.51 \\
\end{array}$ & $\begin{array}{c}100.00 \\
94.69 \\
89.11 \\
80.98 \\
74.42 \\
56.59 \\
43.92 \\
18.17 \\
\end{array}$ & $\begin{array}{c}0.00 \\
5.31 \\
10.89 \\
19.02 \\
25.58 \\
43.41 \\
56.08 \\
81.83 \\
\end{array}$ \\
\hline $\mathrm{t}_{1 / 2}$ (davs) & 31.49 & & 19.65 & & 8.7 & & & \\
\hline
\end{tabular}

exposure at the same temperatures. At alkaline conditions $(\mathrm{pH}=9)$, the results showed a great decomposition effect as the temperature applied increased with increasing the exposure time. The half life values of cadusafos were 31.49 and 19.65 days at $\mathrm{pH}=7$ for 30 and $40^{\circ} \mathrm{C}$, respectively. While at $\mathrm{pH}=9$ at the same temperatures, the corresponding values decreased to 8.75 and 4.07 days, respectively which are in a harmony with those obtained with Kookana et al (1998) and Abdel-El-Hamid (2007) who studied the degradation of some found that cadusafos was more stable at different temperatures, while the influence of UV-rays, sunlight and different $\mathrm{pH}$ 's at different temperatures decrease the stability.

\section{REFERENCES}

Castillo L. E., Martínez, E. Ruepert, C. C. Savage, Gilek, M. Pinnock M. and E. Solis (2006). Water quality and macro invertebrate community response following pesticide applications in a banana plantation, Limon, Costa Rica, 
Science of the Total Environment. 367:418-432.

Ccobb N.A. (1914). U.S. Department of Agriculture Yearbook, , p. 457-490.

Eissa, F.I.; Mahmoud;Hend A. Zidan N.A. and Belal E.B.A. (2006). Microbial, thermal and photodegradation of cadusafos and carbofuran pesticides. J. Pest Cont. \& Environ.Sci. 14(2): 107130.

Jhonson D.P. (1963). Determination of seven insecticide residues in fruit and vegetables. J.A.O.A.C., 46:234-237.

Jones R.L. and Norris. F.A. (1998). Factors affecting the degradation of Aldicarb and ethoprofos. J. of Nematology. 30(1): 45-55.

Kookana, R.S., Baskaran S. and Naidu. R. (1998). Pesticide fate and behavior in Australian soils in relation to contamination and management of soil and water. A review Aust.J. Soil Res. 36:715-764.

Krause M., Loubser J.T. and Beer P.R.De (1986). Residues of Aldicarb and fenamiphos in soil, leave, and fruit from a treated Vineyard. J. Agric. FoodChem., 34: 717-720.

Lee P.W., Stearns; S.M. Hernandez; H. Powell W.R. and Naidu M.V. (1989), Fate of dicrotophos in the soil environment. J.Agric. Food Chem. 27, 1169-1174.

McClure, M.A. and Schmitt. M.E(1996). Suppl. J. Nematol. 28: 624-628.
Molhoff E. (1975), Method for gas chromatographic determination residues of Tokuthion and its oxon in plants and soil samples. PflanzenschutzNachrichaen Bayer, 28: 882-887.

Moye H.A., Malagodi J.Yoh,, Leibee; G.L. $\mathrm{Ku}$ C.C. and Wislocki. P.G. (1987). Residues of overmectin $\mathrm{B}_{1}$ a rotational crops and soils following soil treatment with $\left(\mathrm{C}^{14}\right)$ avermectin $\mathrm{B}_{1}$ a. J.Agric. Food. Chem. 35: 846-859.

Nordmeyer D. in F.J. and Maas,P.W.T. eds. (1992), Nematology: From Molecule to Ecosystem, European Society of Nematologists, Invergowrie, Scotland, p. 266-280.

Plimer J.R. (1970). The photochemistry of halogenated herbicides. Residue Rev. 33: 47-72.

Queneherve, P.; Mateille T. and Topart P. (1991). Effect of cadusafos compared to three other non-fumigant nematicides on the control of nematodes and on the yield of banana cv. Poyo in the Ivory Coast. Revue Nematol. 14(2):251-260.

Raut S.P. and Suvarna R. (2004), Diseases of fruits and vegetables, Vol.II, 37-52.

Abdel-El-Hamid Reem M (2007), Behaviour of Certain Pesticide Residues in Aquatic Environment M. Sc. Degree, Fac. Agric. Ain Shams Univ 66-68.

Smelt J.H. and Leistra, M. in Gommers F.J. and Maas,P.W.T. eds., (1992), Nematology: From Molecule to Ecosystem, European Society of Nematologists, Invergowrie, Scotland, pp. 266-280.

\footnotetext{
ثبات مبيد الكادوسافوس فى تربة بساتين الموز تحت بعض العوامل البيئية المختلفة

نيفين صلاح الدين أحمد$$
\text { المعمل المركزى للمبيدات ـ مركز البحوث الزر اعية ـ الدقى ـ الجيزة-مصر }
$$

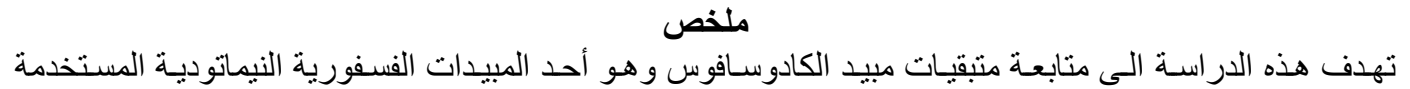

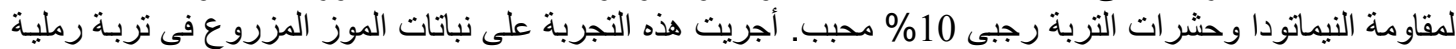

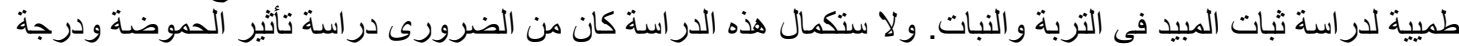

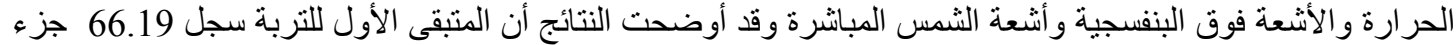

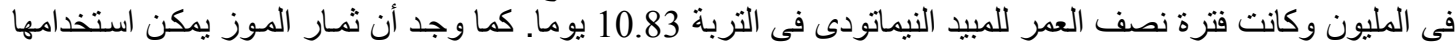

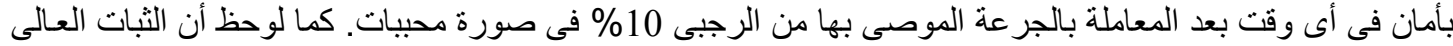

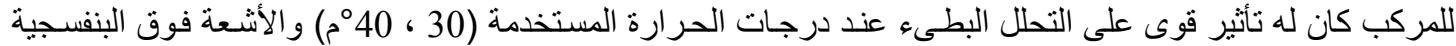

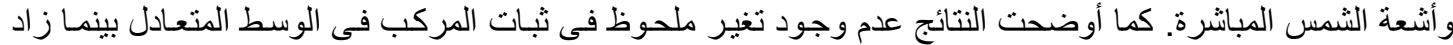
التحلل بدرجة عالية فى الوسط القلوى خاصة عند درجة الحر ارة العالية.
} 